\title{
Allelopathic effect of peanut, sunflower and corn crops on germination and growth of some winter weeds
}

\author{
M.M. Abou El-Enin ${ }^{*}$ and M.A.F. Abdel-Ghffa \\ Department of Agronomy, Faculty of Agriculture, Al-Azhar University, Nasr City, Cairo, EGYPT \\ *Corresponding author's E-mail: magro_modeller@yahoo.com
}

\section{ARTICLE HISTORY}

Received: 22 July 2017

Revised received: 18 October 2017

Accepted: 2 November 2017

\section{Keywords}

Agricultural crops

Allelopathic effect

Interaction effect percent inhibition

Water extract

Winter weeds

\begin{abstract}
The present study was carried out to study the effects of three summer crops water extracts (peanut, sunflower, maize) on germination and seedling growth of six winter weeds (Medicago polymorpha, L., Sonchus oleraceus, L., Lathyrus hirsutus, L., Phalaris minor, Anagallis arvensis, L., Rumex dentatus, L.) and two winter field crops (Beta vulgaris L. and Vicia faba L.) under laboratory conditions. Results revealed that Peanut water extract was recorded the highest mean inhibition values (31.25, 47.81, 89.58 and $74.22 \%$ ) for L. hirsutus, A. arvensis, V. faba and B. vulgaris, respectively. On the other hand, the lowest mean inhibition values $(97.92$ and $85.16 \%)$ were obtained from the maize water extract for $V$. faba and B. vulgaris, respectively. While, the highest inhibition values $(27.50,66.67,59.83 \%)$ were obtained from the interaction effect between Peanut extract with concentration $40 \%$ for $A$. arvensis, $V$. faba and B. vulgaris, the percentage inhibition of them were (69.44, 33.33, and $32.14 \%$ ), respectively. Peanut extract was recorded the highest mean inhibition values $(6.12$ and $7.06 \mathrm{~cm})$ for shoot length of $A$. arvensis and $B$. vulgaris, respectively. On the other hand, maize extract was activated the growth of shoot $V$. faba values $(17.26 \mathrm{~cm})$. In addition, the highest inhibition percentages $(80.22,79.61,75.86,65.64,51.79,25.39$ and $15.66 \%)$ were obtained from $40 \%$ concentration for shoot length of M. polymorpha, $R$. dentatus, A. arvensis, S. oleraceus, $P$. minor, L. hirsutus and B. vulgaris, respectively, as compared with control treatment, in 2014. Moreover, the interaction effect between maize extract and concentration $20 \%$ for was activated growth of shoot length $V$. faba values $(20.15 \mathrm{~cm})$ the percentage inhibition for him $(55.00 \%)$. Peanut extract was recorded the highest mean inhibition values $(1.38,1.81$, and $2.05 \mathrm{~cm})$ for root length of $S$. oleraceus, $P$. minor and $R$. dentatus, respectively. On the other case, Sunflower extract was activated growth of shoot $V$. faba values $(11.86 \mathrm{~cm})$ while, peanut extract was activated the shoot growth of $B$. vulgaris values $(13.58 \mathrm{~cm})$. Also, $20 \%$ concentration was activated the root growth of $B$. vulgaris and $V$. faba (39.36 and $23.79 \%$ ) respectively. The interaction effect between peanut extract and concentration $20 \%$ was activated root growth of $B$. vulgaris values $(15.85 \mathrm{~cm})$, while, sun flower extract with concentration $20 \%$ was activated root growth of $V$. faba values $(14.95 \mathrm{~cm})$. Therefore, the water extracts of peanut, sunflower and maize showed the inhibitory effects on the seedlings of winter weeds.
\end{abstract}

C2017 Agriculture and Environmental Science Academy

Citation of this article: Abou El-Enin, M.M. and Abdel-Ghffa, M.A.F. (2017). Allelopathic effect of peanut, sunflower and corn crops on germination and growth of some winter weeds. Archives of Agriculture and Environmental Science, 2(4): 257-263, DOI: $10.26832 / 24566632.2017 .020402$

\section{INTRODUCTION}

Weeds are the most abundant plant species, which do not only compete with crop plants for nutrients, water, space and light but also give refuge to pests and diseases; and occasionally interfere with crop growth by releasing allelopathic substances into the rhizosphere of the crop plants (Rice, 1984; Kumar and Chopra, 2013, 2016). Weed also interferes with harvest operations thus increase the processing costs and significantly reduce (21-45\%) the crop yields (Ashiq and Ata, 2005; Kumar and Chopra, 2016). There are several methods used for weed control, which include prevention, cultural, mechanical, biological, and chemical means. Weed management is most success when it involves an integrated approach using a variety of methods. Negative effects of chemical herbicides used in the environment resulted in evolution of different weed management strategies (Einhelling, 1996 and Weston, 1996; Kumar, 2015), which can at least reduce the use of herbicides. Although use of herbicides cannot be eliminated, their use can be reduced by exploiting allelopathy as an alternate weed management tool for crop production (Cheema and Khaliq, 2000; and Jabran et al., 2008). Allelopathy provides strategies for natural weed control either by mulching the soil, the use of allelopathic crops as cover crops; preparing water extracts of allelopathic crops and then sprayed over crops and weeds, the use of allelopathic crop as an intercrop, selection of allelopathic crop varieties or identification of new herbicide chemistry (Kumar, 2015).

The study of allelopathic increased in the 1970 and has under- 
gone rapid development since the mid-1990 becoming a popular topic in botany, ecology, agronomy, soil science, horticulture, and other areas of inquiry in recent years. The allelopathic interaction can be one of the significant factors contributing to species distribution and abundance within plant communities and can be important in the success of invasive plants (Chou, 1999; Mallik, 2003; Field et al., 2006; Inderjit et al., 2006; Zheng et al., 2015), such as water hyacinth (Eichhornia crassipes) (Jin et al., 2003; Gao and Li, 2004), spotted knapweed (Centaurea stoebe L. micranthos), Broeckling and Vivanco (2008) and garlic mustard (Alliaria petiolata M. Bieb) (Vaughn and Berhow, 1999). Allelopathy is also thought to be one of the indirect causes of continuous cropping obstacles in agriculture. Allelopathy may be used as a tool in weed management by applying the residues of allelopathic weeds or crop plants as mulches, growing them in successions and leaving their residues in the field (Altieri and Doll, 1978; Drost and Doll, 1980; Putnam and DeFrank, 1979).

The harmful effects of allelopathic substances include inhibition and delays in germination, seed darkening and turgidity, deformation of seedling, declines in roots, radical, stem, and coleoptiles development, swelling and necrosis of root or radical, paleness, lack of root hair, and decreasing in total dry matter (Jackulski and Rudnic, 1994). However, this can be managed in light of accurate screening before use. However, the use of allelopathic water extracts is economical and environment friendly, yet the reduction in weed biomass is less than herbicides and manual weeding. Moreover, for achieving this much weed control two to three sprays are needed which is neither practicable nor desirable. However, it may be possible to use these allelopathic water extracts with reduced rates of herbicides to increase their efficacy (Cheema et al., 2003). The present investigation was aimed to study the effects of water extracts of some crops, its concentration and the interaction effect between them on germination and seedling growth of some winter weeds, Vicia faba and Beta vulgaris after 30 days from sowing in the laboratory.

\section{MATERIALS AND METHODS}

The experiment was conducted in Agronomy Department, Faculty of Agriculture, Cairo, Al-Azhar University, during the year 2014, to study the effects of summer crops water extracts on germination and seedling growth of some winter weeds and some field crops under optimum conditions. The experiment was arranged in completely randomized design with four replications per treatment.

Plant materials: The plant species used in the allelopathic investigation were divided into: (a) donor species (sources of plant extracts), and (b) receiver species (target weeds). The scientific and common names, families, as well as the used parts of the plants investigated for their biological and allelopathic activities are listed in Tables $(1,2)$. Donor plants were collected from fields located in Menouf, El-Monufyia Governorate at ripening stage.

Crops water extracts: Preparation of crops extracts Straw powders of three crops species were used to prepared water extract according to Abdallah et al. (1989) as follows; $25 \mathrm{~g}$ from each of Straw dried ground tissue were placed in $500 \mathrm{ml}$ Erlenmeyer flask with $250 \mathrm{ml}$ of distilled water and mixture was shacked for $6 \mathrm{~h}$ on a horizontal shaker (approximately 160 cycles per minute). All extracts were filtered through cheese cloth to remove debris and finally filtered using (Whatman No. 1) filter paper to have $100 \%$ concentration $(100 \mathrm{~g} / \mathrm{L})$. The leachates of $20 \%\left(20 \mathrm{~cm}^{3} / \mathrm{L}\right), 30 \%\left(30 \mathrm{~cm}^{3} / \mathrm{L}\right)$ and $40 \%(40$ $\left.\mathrm{cm}^{3} / \mathrm{L}\right)$ concentrations were made by diluting the parent leachate with distilled water. All filtered water extracts were frozen in dark glass bottle for subsequent use.

Crop and weed seeds were sodium hypochlorite solution $0.3 \%$ for 5 minutes before germination test. Petri- dished $(9 \mathrm{~cm}$ in diameter) were sterilized autoclave at $121^{\circ} \mathrm{C}$ for 15 minutes and lined later Whatman No. 1 filter paper as a seedbed. The extracts concentrations $(0,20,30$, and $40 \%)$ of crop straw parts evaluated on germination and growth of field crops and weeds seedlings. Fifteen-milliliter (except faba bean wherever 40 milliliter) of each extract or of distilled water control were added to Petri dishes. The Petri dishes were covered and placed in continuous dark in a controlled environment chamber, which provided a constant temperature of $20^{\circ} \mathrm{C}$ according to ISTA (1995).

The Petri dishes of each individual field crop were arranged in completely randomized design with four replications per treatment. After 30 days, number of germinated seeds was counted to determine germination percentage of crop and weed seeds in all treatments. Germination was deemed to occur only after the radical had protruded beyond the seed coat by at least 1 $\mathrm{mm}$.

Data recorded: Germination percentage was recorded after adequate period of each crop according to ISTA (1995). The root length and shoot length was measured using the scale while inhibition percentage was calculated as follows:

Inhibition of germination $(\%)=[($ control - treatment $) /$ control $]$ $\times 100$.

Statistical analyses: The data of each experiment were statistically analyzed as a factorial experiment according to the methods described by little and Hills (1978). The treatments means were compared by least significant differences (LSD) at the 0.05 level of probability.

\section{RESULTS AND DISCUSSION}

\section{Effect of crops water extracts on germination and seedling growth of some weeds and crops under optimum conditions}

Germination percentage (\%): Results presented in Table (3) shows the effect of some crops water extracts (peanut, maize, sunflower) on germination $\%$ of bur clover, sow thistle, and caley pea, lesser canary grass, scarlet pimpernel, dentated dock, broad bean and sugar beet in 2014 season. Results revealed that peanut water extract was recorded the highest mean inhibition values $(31.25,47.81,89.58$ and $74.22 \%)$ for L. hirsutus, A. arvensis, V. faba and B. vulgaris, respectively. In addition, sunflower water extract was recorded the highest mean inhibition values $(24.31,33.25$ and $89.58 \%)$ for $M$. polymorpha, $P$. minor and $V$. faba, respectively. On the other hand, the lowest mean inhibition values (97.92 and 85.16\%) were obtained from the maize water extract for $V$. faba and $B$. vulgaris, respectively. These results are corroborated with the findings of Hall et al. (1982), Leather (1982; 1983) and Naseem et al. (2003).

As for, crops extract concentration percentage gave a significant effect on germination \% in 2014 season (Table 3), the highest inhibition percentage $(89.40,87.77,86.11,75.00$, $73.61,66.20,25.00$ and $21.43 \%$ ) were obtained from $40 \%$ concentration for germination $\%$ of $P$. minor, $S$. oleraceus, $M$. polymorpha, L. hirsutus, $R$. dentatus, A. arvensis, $V$. faba and $B$. vulgaris, respectively, as compared with control treatment for that trait. Cheema (1988) has reported similar selective effects of allelochemicals and Leather (1982, 1983) and 
Naseem (1997), who reported that allelochemicals have selective effect against weed germination and dry matter accumulation. Inhibitory effect increased with the increasing concentration of Phenolics (Cheema, 1988; Hall et al., 1982; Naseem, 1997).

Regarding the interaction effect between crops extracts and extracts concentrations. Results showed that there was a significant effect on germination percentage (\%), the highest inhibition values $(27.50,66.67,59.83 \%)$ were obtained from the interaction effect between peanut extract with concentration $40 \%$ for $A$. arvensis, $V$. faba and B. vulgaris the percentage inhibition of them were $(69.44,33.33$, and $32.14 \%$ ), respectively. Results also cleared that the highest inhibition values $(5.55,5.00,6.00$, and $66.67 \%)$ were obtained from the interaction effect between sun flower extract with concentration $40 \%$ for $M$. polymorpha, S. oleraceus, $P$. minor and $V$. faba the percentage inhibition of them $(91.68,94.94,93.18$ and $33.33 \%$ ), respectively. These results are corroborated with the findings of Hall et al. (1982), Leather $(1982,1983)$ and Naseem et al. (2003).

Shoot length (cm): Table 5 shows the effect of the concentration of water extract of some summer crops on shoot length (cm) of some winter weeds, V. faba and B. vulgaris after 30 days from sowing. Results indicated that the differences between summer crops extracts under study were significant effect on shoot length in 2014 season. Peanut extract was recorded the highest mean inhibition values (6.12 and 7.06 $\mathrm{cm}$ ) for shoot length of $A$. arvensis and $B$. vulgaris, respectively, in addition, sunflower extract was recorded the highest mean inhibition values (7.74 and 12.59) for $P$. minor and $V$. fabea, respectively. On the other hand, maize extract was activated the growth of shoot $V$. fabea values $(17.26 \mathrm{~cm})$.

These results may be attributed to negative effect of chemicals released from peanut and sunflower on growth, consequently, on shoot length of weeds and crops under studied. Cheema et al. (1997), Rice (1984), Ahmad et al. (1991), and Cheema and Ahmad (1992) support these findings. With respect of crops extract concentrations \% gave a significant effect on shoot length in 2014 seasons (Table 4). The results revealed that, the highest inhibition percentages $(80.22,79.61,75.86,65.64$, $51.79,25.39$ and $15.66 \%$ ) were obtained from $40 \%$ concentration for shoot length of $M$. polymorpha, $R$. dentatus, A. arvensis, S. oleraceus, $P$. minor, L. hirsutus and B. vulgaris, respectively, as compared with control treatment, in 2014 season.

At the same time, the results revealed that, the highest stimulation percentages $(18.38 \%)$ were obtained from $20 \%$ concentration for shoot length of $V$. faba as compared with control treatment. The inhibition of shoot growth may be attributed to concentration increase allelochemicals in the shoot and it is active. Cheema (1988) has reported similar selective effects of allelochemicals and Leather $(1982,1983)$ and Naseem (1997), who reported that allelochemicals have selective effect against weed germination and dry matter accumulation. Inhibitory effect increased with the increasing concentration of Phenolics Cheema (1988), Hall et al. (1982), Naseem (1997).

Regarding the interaction effect between crops extracts and extracts concentrations. Results show that this interaction gave significant effect on shoot length trait for most weeds and crops under study. The maximum inhibition value $(0.85$, 5.5 and $11.90 \mathrm{~cm}$ ) were obtained from the interaction effect between sunflower extract and concentration $40 \%$ for $M$. polymorpha, $P$. minor and $V$. faba, respectively, the percentage inhibition of them $(90.65,52.99$ and $8.46 \%)$ respectively, peanut extract with concentrate $40 \%$ values $(6.08,2.08$ and $6.15 \mathrm{~cm}$ ) for L. hirsutus, A. arvensis and B. vulgaris, respectively, the percentage inhibition of them $(31.30,82.07$, and $22.93 \%$ ) respectively, and maize extract with concentrate $40 \%$ values $(3.13$ and $5.50 \mathrm{~cm})$ for $S$. oleraceus and $P$. minor, respectively, the percentage inhibition of them (67.90 and $52.99 \%$ ), respectively. On the other case, the interaction effect between maize extract and concentration $20 \%$ for was activated growth of shoot length $V$. faba values $(20.15 \mathrm{~cm})$ the percentage inhibition for him (55.00\%) Cheema et al. (1997), Rice (1984), Ahmad et al. (1991), and Cheema and Ahmad (1992) support these findings.

Root length (cm): The root length $(\mathrm{cm})$ of bur clover, Sow thistle, Caley pea, lesser canary grass, Scarlet pimpernel, Dent ated dock, broad bean and sugar beet as influenced by some crops water extracts (peanut, maize, sunflower), it concentrations and their interaction in 2014 season are presented in Table 6. Results revealed that root length was significantly affected by crops water extracts (peanut, maize, sunflower) under study. Peanut extract was recorded the highest mean inhibition values $(1.38,1.81$, and $2.05 \mathrm{~cm})$ for root length of $S$. oleraceus, $P$. minor, and $R$. dentatus, respectively, as for, Sun flower extract was recorded the highest mean inhibition values (5.58 and $1.81 \mathrm{~cm})$ for L. hirsutus, and P. minor, respectively, as for, maize extract was recorded the highest mean inhibition values (1.64. and $9.63 \mathrm{~cm}$ ) for $M$. polymorpha and B. vulgaris, respectively. On the other hand, sunflower extract was activated growth of shoot $V$. faba values $(11.86 \mathrm{~cm})$ while peanut extract was activated growth of shoot $B$. vulgaris values $(13.58 \mathrm{~cm})$. These results are in agreement with Wilson and Rice (1968), Macias et al. (1998, 2002) and Anjum, and Bajwa (2005).

Results presented in Table 4 raveled that the differences between crops extracts concentrations were significant for root length $(\mathrm{cm})$ in 2014 season. The highest inhibition percentage $(90.16,90.00,84.05,81.74,60.76$ and $56.95 \%)$ was obtained from $40 \%$ concentration for root length of $P$. minor, $S$. oleraceus, $M$. polymorpha, A. arvensis, L. hirsutus and $R$. dentatus, respectively. On contradictory, $20 \%$ concentration was activated the root growth of $B$. vulgaris and $V$. faba (39.36 and $23.79 \%$ ), respectively. These results are in agreement with Cheema (1988), has reported similar selective effects of allelochemicals and Leather $(1982,1983)$ and Naseem (1997), who reported that allelochemicals have selective effect against weed germination and dry matter accumulation. Inhibitory effect increased with the increasing concentration of Phenolics (Cheema, 1988; Hall et al. 1982; Naseem, 1997).

The interaction effect between crops extracts and extracts concentrations $\%$ was significant effect on this trait. The highest inhibition values $(0.25,0.45$ and $1.08 \mathrm{~cm})$ were obtained from the interaction effect between Peanut extract with concentration $40 \%$ for $S$. oleraceus, $P$. minor, and $R$. dentatus the percentage inhibition of them $(93.90,90.78$ and $63.39 \%)$ respectively, while, the interaction effect between sunflower extract and concentration $40 \%$ recorded the highest inhibition values $(3.50$ and $0.45 \mathrm{~cm})$ for L. hirsutus and $P$. minor the percentage inhibition of them (63.27 and $90.78 \%)$ respectively, results also showed that the highest inhibition values for M. polymorpha, $V$. faba and B. vulgaris $(0.53,9.20$ and $8.93 \mathrm{~cm}$ ), respectively, were obtained by the interaction effect between maize extract and concentration $40 \%$, and the percentage inhibition of them (87.38, 1.39 and 8.41\%), respectively. On contrary, the interaction effect between 
Peanut extract and concentration $20 \%$ was activated root growth of $B$. vulgaris values $(15.85 \mathrm{~cm})$ and the percentage inhibition for it was $(62.56 \%)$, while, sun flower extract with concentration $20 \%$ was activated root growth of $V$. faba values $(14.95 \mathrm{~cm})$ and the percentage inhibition for it was $(60.24 \%)$. These results are corroborated with the findings of Hall et al. (1982), Cheema (1988), Leather (1982, 1983) and Naseem et al. (2003).

Table 1. Plants investigated for their biological and allelopathic activities.

Donor species (Sources of plant extracts)

\begin{tabular}{cllll}
\hline S.N. & Scientific name & Family & Common name & Used part \\
\hline 1 & Arachis hypogaea L. & Leguminous & Peanut & Straw \\
2 & Helianthus annuus L. & Compositeae & sunflower & Straw \\
3 & Zea mays L. & Poaceae & Corn & Straw \\
\hline
\end{tabular}

Table 2. Description of winter crops and weeds used in the study.

\begin{tabular}{llll}
\hline & & Winter crops & \\
\hline S.N. & Scientific name & Family & Common name \\
\hline 1 & Vicia faba $\mathrm{L}$. & Leguminous & Broad bean \\
2 & Beta vulgaris $\mathrm{L}$. & Chenopodiaceae & Sugar beet \\
\hline & & Winter weeds & \\
\hline 1 & Medicago polymorpha $\mathrm{L}$. & Leguminosae & Bur clover or toothed medik \\
2 & Sonchus oleraceus $\mathrm{L}$. & Compositae & Sow-thistle \\
3 & Lathyrus hirsutus $\mathrm{L}$. & Leguminosae & Caley pea or hairy vetch ling \\
4 & Phalaris minor Retz. & Poaceae & lesser-canary grass or small canary grass \\
5 & Anagallis arvensis $\mathrm{L}$. & Primulaceae & Scarlet pimpernel \\
6 & Rumex dentatus $\mathrm{L}$. & Polygonaceae & Dentated dock or Toothed dock \\
\hline
\end{tabular}

Table 3. Effect of water extract of some crops, it concentration and the interaction between them on germination \% of some winter weeds, $V$. faba and $B$. vulgaris after 30 days from sowing.

\begin{tabular}{|c|c|c|c|c|c|c|c|c|c|}
\hline \multicolumn{2}{|c|}{ Treatments } & \multicolumn{5}{|c|}{ Germination \% (Lab.) } & \multirow[b]{2}{*}{$\begin{array}{c}R . \\
\text { dentatus }\end{array}$} & \multirow[b]{2}{*}{$\begin{array}{c}V . \\
f a b a\end{array}$} & \multirow[b]{2}{*}{$\begin{array}{c}\text { B } \\
\text { vulgaris }\end{array}$} \\
\hline Extracts & Concentration & $\begin{array}{c}\text { M. } \\
\text { polymorpha }\end{array}$ & $\begin{array}{c}S . \\
\text { oleraceus }\end{array}$ & $\begin{array}{c}L . \\
\text { hirsutus }\end{array}$ & $\begin{array}{c}P . \\
\text { minor }\end{array}$ & $\begin{array}{c}\text { A. } \\
\text { arvensis }\end{array}$ & & & \\
\hline \multirow{4}{*}{ Pea nut } & $0 \%$ & 66.67 & 98.75 & 66.67 & 88.00 & 90.00 & 85.71 & 100.00 & 87.50 \\
\hline & $20 \%$ & 44.44 & 30.00 & 20.83 & 42.00 & 40.00 & 78.57 & 100.00 & 81.25 \\
\hline & $30 \%$ & 13.89 & 10.00 & 20.83 & 13.00 & 33.75 & 32.14 & 91.67 & 68.75 \\
\hline & $40 \%$ & 11.11 & 10.00 & 16.67 & 9.00 & 27.50 & 21.43 & 66.67 & 59.38 \\
\hline \multirow[t]{2}{*}{ Mean } & & 34.03 & 37.19 & 31.25 & 38.00 & 47.81 & 54.46 & 89.58 & 74.22 \\
\hline & $0 \%$ & 66.67 & 98.75 & 66.67 & 88.00 & 90.00 & 85.71 & 100.00 & 87.50 \\
\hline \multirow{3}{*}{ Maize } & $20 \%$ & 36.11 & 37.50 & 45.83 & 49.00 & 46.25 & 67.86 & 100.00 & 87.50 \\
\hline & $30 \%$ & 25.00 & 31.25 & 33.33 & 21.00 & 37.50 & 35.71 & 100.00 & 87.50 \\
\hline & $40 \%$ & 16.67 & 26.25 & 16.67 & 13.00 & 31.25 & 25.00 & 91.67 & 78.13 \\
\hline \multirow[t]{2}{*}{ Mean } & & 36.11 & 48.44 & 40.63 & 42.75 & 51.25 & 53.57 & 97.92 & 85.16 \\
\hline & $0 \%$ & 66.67 & 98.75 & 66.67 & 88.00 & 90.00 & 85.71 & 100.00 & 87.50 \\
\hline \multirow{3}{*}{ Sun flower } & $20 \%$ & 19.44 & 18.75 & 29.17 & 26.00 & 46.25 & 71.43 & 100.00 & 84.38 \\
\hline & $30 \%$ & 11.11 & 12.50 & 29.17 & 13.00 & 41.25 & 32.14 & 91.67 & 75.00 \\
\hline & $40 \%$ & 5.55 & 5.00 & 16.67 & 6.00 & 32.50 & 21.43 & 66.67 & 68.75 \\
\hline \multirow[t]{2}{*}{ Mean } & & 24.31 & 32.50 & 35.42 & 33.25 & 52.50 & 52.68 & 89.58 & 78.91 \\
\hline & $0 \%$ & 66.67 & 98.75 & 66.67 & 88.00 & 90.00 & 85.71 & 100.00 & 87.50 \\
\hline \multirow{3}{*}{$\begin{array}{c}\text { G.M. } \\
\text { Concentration }\end{array}$} & $20 \%$ & 33.33 & 28.75 & 31.94 & 39.00 & 44.17 & 72.62 & 100.00 & 84.38 \\
\hline & $30 \%$ & 16.67 & 17.92 & 27.78 & 15.67 & 37.50 & 33.33 & 94.44 & 77.08 \\
\hline & $40 \%$ & 9.26 & 12.08 & 16.67 & 9.33 & 30.42 & 22.62 & 75.00 & 68.75 \\
\hline \multicolumn{10}{|l|}{ LSD at $5 \%$} \\
\hline \multicolumn{2}{|l|}{ Extracts } & 1.11 & NS & 1.50 & 0.48 & 0.55 & NS & 1.33 & 0.88 \\
\hline \multicolumn{2}{|l|}{ Concentration } & 1.56 & 3.01 & 2.00 & 0.64 & 0.70 & 2.29 & 2.00 & 1.13 \\
\hline \multicolumn{2}{|c|}{ Extracts $\times$ Concentration } & 4.56 & 9.02 & NS & 1.92 & NS & NS & 6.00 & 3.38 \\
\hline
\end{tabular}


Table 4. Average inhibition of water extract concentration of some crops on germination \%, shoot length and root length (cm) of some winter weeds, $V$. faba and B. vulgaris after 30 days from sowing.

\begin{tabular}{|c|c|c|c|c|c|c|c|c|c|}
\hline \multirow[b]{2}{*}{$\begin{array}{c}\text { Water extract } \\
\text { Concentrations \% }\end{array}$} & \multirow[b]{2}{*}{ Crop traits } & \multicolumn{8}{|c|}{ Average inhibition at a different concentrations } \\
\hline & & $\begin{array}{c}M . \\
\text { polymorpha }\end{array}$ & $\begin{array}{c}S . \\
\text { oleraceus }\end{array}$ & $\begin{array}{c}L . \\
\text { hirsutus }\end{array}$ & $\begin{array}{c}P . \\
\text { minor }\end{array}$ & $\begin{array}{c}A . \\
\text { arvensis }\end{array}$ & $\begin{array}{c}R . \\
\text { dentatus }\end{array}$ & $\begin{array}{c}V . \\
f a b a\end{array}$ & $\begin{array}{c}B . \\
\text { vulgaris }\end{array}$ \\
\hline \multirow{3}{*}{$20 \%$} & Germination \% & 50.01 & 70.89 & 52.09 & 55.68 & 50.92 & 15.27 & 0.00 & 3.57 \\
\hline & Shoot length & 48.00 & 42.05 & 14.61 & 22.31 & 42.07 & 13.29 & -18.38 & 5.14 \\
\hline & Root length & 36.19 & 70.00 & 45.96 & 64.55 & 31.30 & 14.24 & -23.79 & -39.36 \\
\hline \multirow{3}{*}{$30 \%$} & Germination \% & 75.00 & 81.85 & 58.33 & 82.19 & 58.33 & 61.11 & 5.56 & 11.91 \\
\hline & Shoot length & 60.22 & 57.54 & 19.40 & 43.33 & 60.00 & 25.29 & -16.77 & 10.28 \\
\hline & Root length & 56.43 & 79.76 & 53.93 & 79.92 & 64.35 & 37.63 & -22.51 & -17.13 \\
\hline \multirow{3}{*}{$40 \%$} & Germination \% & 86.11 & 87.77 & 75.00 & 89.40 & 66.20 & 73.61 & 25.00 & 21.43 \\
\hline & Shoot length & 80.22 & 65.74 & 25.39 & 51.79 & 75.86 & 79.61 & -16.23 & 15.66 \\
\hline & Root length & 84.05 & 90.00 & 60.76 & 90.16 & 81.74 & 56.95 & -8.25 & -10.38 \\
\hline
\end{tabular}

Table 5. The effect of water extract of some crops, it concentration and the interaction between them on shoot length $(\mathrm{cm})$ of some winter weeds, $V$. faba and B. vulgaris after 30 days from sowing.

\begin{tabular}{|c|c|c|c|c|c|c|c|c|c|}
\hline \multicolumn{2}{|c|}{ Treatments } & \multicolumn{5}{|c|}{ (Lab.) Shoot length } & \multirow[b]{2}{*}{ R. dentatus } & \multirow[b]{2}{*}{ V. faba } & \multirow[b]{2}{*}{ B. vulgaris } \\
\hline Extracts & Concentration & M. polymorpha & S. oleraceus & L. hirsutus & P. minor & A. arvensis & & & \\
\hline \multirow{4}{*}{ Pea nut } & $0 \%$ & 9.00 & 9.75 & 8.85 & 11.70 & 11.60 & 7.75 & 13.00 & 7.98 \\
\hline & $20 \%$ & 5.63 & 5.13 & 6.28 & 9.35 & 7.20 & 6.55 & 13.23 & 7.55 \\
\hline & $30 \%$ & 4.00 & 3.65 & 6.10 & 6.38 & 3.60 & 5.75 & 14.53 & 6.55 \\
\hline & $40 \%$ & 1.25 & 3.53 & 6.08 & 5.93 & 2.08 & 1.15 & 15.93 & 6.15 \\
\hline \multirow[t]{2}{*}{ Mean } & & 4.97 & 5.51 & 6.83 & 8.34 & 6.12 & 5.30 & 14.17 & 7.06 \\
\hline & $0 \%$ & 9.00 & 9.75 & 8.10 & 11.70 & 11.60 & 7.75 & 13.00 & 7.98 \\
\hline \multirow{3}{*}{ Maize } & $20 \%$ & 3.70 & 6.50 & 7.40 & 10.83 & 7.25 & 6.85 & 20.15 & 7.40 \\
\hline & $30 \%$ & 3.38 & 4.03 & 6.73 & 6.88 & 5.78 & 5.83 & 18.38 & 7.23 \\
\hline & $40 \%$ & 3.25 & 3.13 & 6.13 & 5.50 & 2.63 & 1.73 & 17.50 & 6.98 \\
\hline \multirow[t]{2}{*}{ Mean } & & 4.83 & 5.85 & 7.09 & 8.73 & 6.81 & 5.54 & 17.26 & 7.39 \\
\hline & $0 \%$ & 9.00 & 9.75 & 8.10 & 11.70 & 11.60 & 7.75 & 13.00 & 7.98 \\
\hline \multirow{3}{*}{ Sun flower } & $20 \%$ & 4.70 & 5.33 & 7.70 & 7.10 & 5.70 & 6.75 & 12.80 & 7.75 \\
\hline & $30 \%$ & 3.38 & 4.75 & 7.35 & 6.65 & 4.55 & 5.80 & 12.65 & 7.70 \\
\hline & $40 \%$ & 0.85 & 3.38 & 6.50 & 5.50 & 3.70 & 1.85 & 11.90 & 7.05 \\
\hline Mean & & 4.48 & 5.80 & 7.41 & 7.74 & 6.39 & 5.54 & 12.59 & 7.62 \\
\hline \multicolumn{2}{|c|}{ Overall mean extracts } & 4.76 & 5.72 & 7.11 & 8.27 & 6.44 & 5.46 & 14.67 & 7.36 \\
\hline & $0 \%$ & 9.00 & 9.75 & 8.35 & 11.70 & 11.60 & 7.75 & 13.00 & 7.98 \\
\hline G.M. & $20 \%$ & 4.68 & 5.65 & 7.13 & 9.09 & 6.72 & 6.72 & 15.39 & 7.57 \\
\hline \multirow[t]{2}{*}{ Concentration } & $30 \%$ & 3.58 & 4.14 & 6.73 & 6.63 & 4.64 & 5.79 & 15.18 & 7.16 \\
\hline & $40 \%$ & 1.78 & 3.34 & 6.23 & 5.64 & 2.80 & 1.58 & 15.11 & 6.73 \\
\hline \multicolumn{10}{|l|}{ LSD at $5 \%$} \\
\hline \multicolumn{2}{|l|}{ Extracts } & NS & NS & NS & 0.12 & 0.06 & NS & 0.07 & 0.08 \\
\hline \multicolumn{2}{|l|}{ Concentration } & 0.14 & 0.14 & 0.21 & 0.16 & 0.09 & 0.08 & 0.09 & 0.11 \\
\hline \multicolumn{2}{|c|}{ Extracts $\times$ Concentration } & 0.42 & 0.41 & NS & 0.48 & 0.26 & NS & 0.27 & NS \\
\hline
\end{tabular}

Table 6. Effect of water extract of some crops, it concentration and the interaction between them on root length (cm) of some winter weeds, $V$. faba and B. vulgaris after 30 days from sowing.

\begin{tabular}{|c|c|c|c|c|c|c|c|c|c|}
\hline \multirow[b]{2}{*}{ Extracts } & \multicolumn{2}{|l|}{ Treatments } & \multicolumn{6}{|c|}{ Root length (cm) (Lab.) } & \multirow[b]{2}{*}{$\begin{array}{c}\text { B. } \\
\text { vulgaris }\end{array}$} \\
\hline & Concentration & $\begin{array}{c}M . \\
\text { polymorpha }\end{array}$ & $\begin{array}{c}S . \\
\text { oleraceus }\end{array}$ & $\begin{array}{c}L . \\
\text { hirsutus }\end{array}$ & P. minor & A. arvensis & $\begin{array}{c}\mathrm{R} . \\
\text { dentatus }\end{array}$ & $\begin{array}{c}V . \\
f a b a\end{array}$ & \\
\hline \multirow{4}{*}{ Pea nut } & $0 \%$ & 4.20 & 4.10 & 9.53 & 4.88 & 2.30 & 2.95 & 9.33 & 9.75 \\
\hline & $20 \%$ & 3.43 & 0.80 & 4.90 & 1.18 & 1.68 & 2.58 & 10.00 & 15.85 \\
\hline & $30 \%$ & 2.45 & 0.38 & 4.35 & 0.73 & 0.85 & 1.60 & 11.08 & 14.83 \\
\hline & $40 \%$ & 0.78 & 0.25 & 3.80 & 0.45 & 0.45 & 1.08 & 11.85 & 13.88 \\
\hline \multirow[t]{2}{*}{ Mean } & & 2.71 & 1.38 & 5.64 & 1.81 & 1.32 & 2.05 & 10.56 & 13.58 \\
\hline & $0 \%$ & 4.20 & 4.10 & 9.53 & 4.88 & 2.30 & 2.95 & 9.33 & 9.75 \\
\hline \multirow{3}{*}{ Maize } & $20 \%$ & 1.10 & 1.13 & 5.50 & 3.03 & 1.45 & 2.30 & 9.70 & 10.65 \\
\hline & $30 \%$ & 0.75 & 0.83 & 4.58 & 1.25 & 0.80 & 2.30 & 9.33 & 9.18 \\
\hline & $40 \%$ & 0.53 & 0.33 & 3.93 & 0.53 & 0.38 & 1.63 & 9.20 & 8.93 \\
\hline \multirow[t]{2}{*}{ Mean } & & 1.64 & 1.59 & 5.88 & 2.42 & 1.23 & 2.29 & 9.39 & 9.63 \\
\hline & $0 \%$ & 4.20 & 4.10 & 9.53 & 4.88 & 2.30 & 2.95 & 9.33 & 9.40 \\
\hline \multirow{3}{*}{ Sun flower } & $20 \%$ & 3.50 & 1.75 & 5.05 & 0.98 & 1.63 & 2.70 & 14.95 & 13.75 \\
\hline & $30 \%$ & 2.28 & 1.30 & 4.25 & 0.95 & 0.80 & 1.63 & 13.90 & 9.85 \\
\hline & $40 \%$ & 0.70 & 0.65 & 3.50 & 0.45 & 0.43 & 1.10 & 9.25 & 9.08 \\
\hline Mean & & 2.67 & 1.95 & 5.58 & 1.81 & 1.29 & 2.09 & 11.86 & 10.52 \\
\hline \multicolumn{2}{|c|}{ Overall mean extracts } & 2.34 & 1.64 & 5.70 & 2.01 & 1.28 & 2.15 & 10.60 & 11.24 \\
\hline & $0 \%$ & 4.20 & 4.10 & 9.53 & 4.88 & 2.30 & 2.95 & 9.33 & 9.63 \\
\hline G.M. & $20 \%$ & 2.68 & 1.23 & 5.15 & 1.73 & 1.58 & 2.53 & 11.55 & 13.42 \\
\hline \multirow[t]{2}{*}{ Concentration } & $30 \%$ & 1.83 & 0.83 & 4.39 & 0.98 & 0.82 & 1.84 & 11.43 & 11.28 \\
\hline & $40 \%$ & 0.67 & 0.41 & 3.74 & 0.48 & 0.42 & 1.27 & 10.10 & 10.63 \\
\hline \multicolumn{10}{|l|}{ LSD at $5 \%$} \\
\hline \multicolumn{2}{|l|}{ Extracts } & 0.05 & 0.03 & 0.03 & 0.03 & NS & 0.02 & 0.08 & 0.07 \\
\hline \multicolumn{2}{|l|}{ Concentration } & 0.07 & 0.04 & 0.04 & 0.04 & 0.03 & 0.03 & 0.10 & 0.10 \\
\hline \multicolumn{2}{|c|}{ Extracts $\times$ Concentration } & 0.20 & 0.12 & 0.13 & 0.12 & NS & 0.09 & 0.31 & 0.29 \\
\hline
\end{tabular}




\section{Conclusions}

The present study concluded that the differences between summer crops extracts under study were significant effect on shoot length in 2014 season. The sunflower water extract was recorded the highest mean inhibition values $(24.31,33.25$ and $89.58 \%$ ) for $M$. polymorpha, $P$. minor and $V$. faba, respectively while, the lowest mean inhibition values (97.92 and $85.16 \%$ ) were obtained from the maize water extract for $V$. faba and B. vulgaris, respectively. Peanut extract was recorded the highest mean inhibition values $(6.12$ and $7.06 \mathrm{~cm})$ for shoot length of $A$. arvensis and $B$. vulgaris, respectively, in addition, sunflower extract was recorded the highest mean inhibition values (7.74 and 12.59) for P. minor and $V$. fabea, respectively. Thus, the water extracts of peanut, sunflower and maize showed the inhibitory effects on the seedlings of winter weeds (M. polymorpha, S. oleraceus, L. hirsutus, P. minor, A. arvensis, and $R$. dentatus).

Open Access: This is open access article distributed under the terms of the Creative Commons Attribution License, which permits unrestricted use, distribution, and reproduction in any medium, provided the original author(s) and the source are credited.

\section{REFERENCES}

Abdallah, M.F., Elmore, C.L. and Khalaf, K.A. (1989). Allelopathic effects of tomato root extract on the germination of some weed seeds. Egyptian journal of horticulture, 16(1): 25-33.

Ahmad, S., Cheema, Z.A. and Mahmoud, A. (1991). Response of some rabi weeds and wheat to allelopathic effects of irrigated sorghum in a sorghum wheat cropping system. Pakistan Journal of Weed Science Research, 4: 81-88.

Altieri, M.A. and Doll, J.D. (1978). The potential of allelopathy as a tool for weed management in crops. PANS, 24(4): 495-502, DOI: $10.1080 / 09670877809414143$.

Anjum, T. and Bajwa, R. (2005). A bioactive annuionone from sunflower leaves. Phytochemistry, 66: 1919-1921.

Ashiq, M. and Ata, Z. (2005). Effective use of herbicides, p: 7. Weed Science Allelopathy Lab., Department of Agronomy, University of Agriculture, Faisalabad, Pakistan.

Broeckling, C.D. and Vivanco, J.M. (2008). A selective, sensitive, and rapid in-field assay for soil catechin, an allelochemical of Centaurea maculosa. Soil Biology and Biochemistry, 40: 11891196.

Cheema, Z.A. (1988). Weed control in wheat through sorghum allelochemicals. Ph.D. Thesis. Department of Agronomy, University of Agriculture, Faisalabad, Pakistan.

Cheema, Z.A. and Ahmad, S. (1992). Allelopathy: A potential tool for weed management. Proc. Nat. Seminar on the Role of Plant Health and Care in Agriculture, pp: 151-6. Prod. Held on Dec. 28-29, 1988 at Univ. of Agri., Faisalabad, Pub. Univ. Agri., Press, Faisalabad.

Cheema, Z.A. and Khaliq A. (2000). Use of sorghum allelopathic properties to control weeds in irrigated wheat in a semi-arid region of Punjab. Agriculture Ecosystem and Environment, 79: $105-112$.

Cheema, Z.A., Hussain, S. and Khaliq, A. (2003). Efficacy of sorgaab in combination with allelopathic water extracts and reduced rates of pendimethalin for weed control in Mungbean. Indus Journal of Plant Science, 2: 21-25.

Cheema, Z.A., Luqman, M. and Khaliq, A. (1997). Use of allelopathic extracts of sorghum and sunflower herbage for weed control in wheat. Journal of Animal and Plant Sciences, 7: 91-93.

Chou, C.H. (1999). Roles of allelopathy in plant biodiversity and sustainable agriculture. Critical Reviews in Plant Sciences, 18: 609-636.

Drost, D.C. and Doll, J.D. (1980). The allelopathic effect of yellow nutsedge (Cyperus esculentus) on corn and soybeans. Weed Science, 28: 229-233.
Einhelling, F.A. (1996). Interactions involving allelopathy in cropping systems: Allelopathy in cropping systems. Agronomy Journal, 88: 883-893.

Field, B., Jordan, F., and Osbourn, A. (2006). First encountersdeployment of defence-related natural products by plants. New Phytologist, 172: 193-207.

Gao, L. and Li, B. (2004). The study of a specious invasive plant, water hyacinth (Eichhornia crassipes): achievements and challenges. Chinese Journal of Plant Ecology, 28: 735-752.

Hall, A.B., Blum, U. and Fites, R.C. (1982). Stress modification of allelopathy of Helianthus annuus L. debris on seed germination. American journal of Botany, 69: 776-783.

Inderjit, Callaway, R.M., and Vivanco, J.M. (2006). Can plant biochemistry contribute to understanding of invasion ecology? Trends in Plant Science, 11: 574-580.

ISTA. (1995). Handbook of vigour test methods, 3rd edn. Hampton JGd TeKrony DM, eds. Zurich: International Seed Testing Association.

Jabran, K., Cheema, Z.A., Farooq, M., Basra, S.M.A., Hussain, M. and Rehman, H. (2008). Tank mixing of allelopathic crop water extracts with pendimethalin helps in the management of weeds in canola (Brassica napus) field. International Journal of Agriculture \& Biology, 10(3): 293-6.

Jackulski, D. and Rudnic, F. (1994). Mutural effects between species of cereals in the course of germination. Fragmenta Agronomica, 11: 89-94.

Jin, Z.H., Zhuang, Y.Y., Dai, S.G. and Li, T.L. (2003). Isolation and identification of extracts of Eichhornia crassipes and their allelopathic effects on algae. Bulletin of Environmental Contamination and Toxicology, 71: 1048-1052.

Kumar, V. (2015). A review on efficacy of biopesticides to control the agricultural insect's pest. International Journal of Agricultural Science Research, 4(9): 168-179.

Kumar, V. and A.K. Chopra (2016). Influence of summer tillage on soil characteristics, weeds diversity and crop yield of certain vegetable crops grown in Tarai region of Ganga River, India. International Journal of Agricultural Science Research, 5(3): 040-050.

Kumar, V. and Chopra, A.K. (2013). Reduction of weeds and improvement of soil quality and yield of wheat by tillage in Northern Great Plains of Ganga River in India. International Journal of Agricultural Science Research, 2(8): 249-257.

Leather, G. R. (1982). Weed control using allelopathic crop plants. Journal of Chemical Ecology, 9(8): 983-989.

Leather, G.R. (1983). Sunflowers (Helianthus annuus) are allelopathic to weeds. Weed Science, 31: 37-42.

Little, T.M. and Hills, F.J. (1978). Agricultural experimentation: design and analysis. New York: John Wiley and Sons, Inc.; 1978.

Macias, F.A., Ascension, T., Galindo, J.L.G., Rosa, M., Varela, A.J. and Molinillo, J. M. G. (2002). Bioactive terpinoids from sunflower leaves cv. Peredovick. Phytochemistry, 61: 687-692.

Macias. F., Varela, R.M., Torres, A., Oliva, R.M. and Molinillo J.M.G (1998). Bioactive noersquiterpenes from Helianthus annuus with potential allelopathic activity. Phytochemistry, 48: 631-636.

Mallik, A.U. (2003). Conifer regeneration problems in boreal and temperate forests with ericaceous understory: Role of disturbance, seedbed limitation, and keystone species change. Critical Reviews in Plant Sciences, 22: 341-366.

Naseem, M. (1997). Allelopathic effects of autumn sunflower residues on wheat productivity and wheat-weeds. Ph.D. Thesis, Dept. of Agronomy, Univ. of Agriculture, Faisalabad, Pakistan.

Naseem, M., Cheema Z.A. and Bazmi, S.A. (2003). Allelopathic effects of sunflower aqueous extracts on germination of wheat and some important wheat weeds. Pakistan Journal of Scientific Research, 55 (3-4): 71-75.

Putnam, A.R. and DeFrank, J. (1979). Use of cover crops to inhibit weeds. In Proc. IX International Congress of Plant Protection, pp. 580-582.

Rice, E.L. (1984). Allelopathy. p. 309-316. 2nd ed. Academic Press Inc., London, UK. 
Vaughn, S.F. and Berhow, M.A. (1999). Allelochemicals isolated from tissues of the invasive weed garlic mustard (Alliaria petiolata). Journal of Chemical Ecology, 25(11): 2495-2504, DOI: 10.1023/A:1020874124645.

Weston, L.A. (1996). Utilization of allelopathy for weed management in agro ecosystems. Agronomy Journal, 88: 860-866.

Wilson, R.E. and Rice, E.L. (1968). Allelopathy as expressed by
Helianthus annuus and its role in old-field succession. Bulletin of the Torrey Botanical Club, 95(5): 432-448, DOI: 10.2307/2483475. Zheng, Y.L., Feng, Y.L., Zhang, L.K., Callaway, R.M., Valiente-Banuet, A. and Luo, D.Q. (2015). Integrating novel chemical weapons and evolutionarily increased competitive ability in success of a tropical invader. New Phytologist, 205(3): 1350-1359, DOI: 10.1111/ nph. 13135 . 